Article

\title{
Urbanization Patterns around the North Sea: Long-Term Population Dynamics, 1300-2015
}

\author{
Yvonne van Mil* and Reinout Rutte \\ Faculty of Architecture and the Built Environment, Delft University of Technology, The Netherlands; \\ E-Mails: y.b.c.vanmil@tudelft.nl (Y.v.M.), r.j.rutte@tudelft.nl (R.R.) \\ * Corresponding author
}

Submitted: 30 January 2021 | Accepted: 2 April 2021 | Published: 27 July 2021

\begin{abstract}
Around the North Sea, how have port cities and cities in the hinterlands of port cities influenced one another in the past? What possible links are there between population trends in various urban areas and time periods? Is it possible to identify the origin of the urbanization patterns around the North Sea? To understand the current era of urbanization, we need to analyze historical trends and urbanization patterns in the long term. By mapping the population figures for eight moments in history and combining this with data on political boundaries and large infrastructures that facilitate flows of goods and people, this article aims to contribute to an improved understanding of contemporary and historical urbanization trends around the North Sea. It also presents the first spatial dataset on urban settlements around the North Sea by means of a series of demographic maps, from 1300 to 2015. It provides a detailed explanation of the method used for mapping and handling demographical data. Each map is accompanied by a brief explanation of the urbanization pattern, with special attention to identifying demographic and economic developments and possible clarifications for centers of gravity and shifts. The maps lay the foundation for further research on social patterns and spatial developments in urban (port) regions around the North Sea and for understanding urban culture through space and time. Port cities must be analyzed from the perspective of the sea, which requires a rethinking of data sets and data borders, to understand the ways in which these port cities have served as porous distribution hubs and as transit nodes for boundary-crossing flows.
\end{abstract}

\section{Keywords}

demography; geo-spatial mapping; infrastructure; North Sea region; political boundaries; population numbers; port cities; urbanization patterns

\section{Issue}

This article is part of the issue "Planning for Porosity: Exploring Port City Development through the Lens of Boundaries and Flows" edited by Carola Hein (Delft University of Technology, The Netherlands).

(C) 2021 by the authors; licensee Cogitatio (Lisbon, Portugal). This article is licensed under a Creative Commons Attribution 4.0 International License (CC BY).

\section{Introduction}

Viewed from land and from various countries with their boundaries, the North Sea is often perceived as a barrier. In The Edge of the World: How the North Sea Made Us Who We Are, Pye (2014) argues that the world looks different when the sea is perceived as facilitating movement: Land becomes a barrier and the sea the bearer of trade and prosperity. The North Sea is an important link in shipping routes and connects Europe with the rest of the world. For centuries, people and goods have flowed through and around the North Sea. Areas near the sea are linked by shipping, trade, and the exchange of products and people passing through port cities. These port cities facilitate flows of goods and people between a maritime foreland and cities in the hinterland. Ports are porous, so to speak, because they facilitate flows that pass boundaries. This porosity generates urbanization around the port and in an often-transnational hinterland connected to the port city 
through infrastructure (see the editorial of this thematic issue of Urban Planning).

Around the North Sea, port cities and the cities in their hinterlands have been influencing one another throughout history (Couling \& Hein, 2020). Academic research on urbanization is often nationally oriented, focused on a specific country, and often attention is paid only to developments that took place either up to the Industrial Revolution or from the Industrial Revolution onwards (De Vries, 1984; Lawton \& Lee, 2002). By looking at urbanization from the perspective of the sea, we can overcome the limitations of national thinking. To understand the current urbanization pattern of cities around the North Sea, it is also helpful to consider a longer time frame, starting with city formation in the 11th-14th centuries up to the present. But how it is possible to get a grip on developments over such a long-term and across such a large area? In this exploratory article we use population numbers of cities around the North Sea, not dictated by national borders, as an indicator. We limit ourselves to: 1) explaining how to classify, unify, and map the data; and 2) describing the urbanization patterns and shifts that become visible on the maps and exploring the possible causes of these shifts.

\section{Method for Mapping and Ranking Data}

Geographically, the North Sea is shaped by the coastlines of Norway, Denmark, Germany, the Netherlands, Belgium, France, and the United Kingdom. In the south it borders the Strait of Dover near Calais; in the north, the Atlantic Ocean. But what does the area around the North Sea consist of? One may argue about that. Throughout history, the North Sea has been described from multiple perspectives by travelers, researchers, and scientists (Blass, 2016; Couling \& Hein, 2020; Pye, 2014). It has also been mapped countless times and for many purposes, from navigation to propaganda. In this study we focus on the urbanization patterns around the North Sea, with the sea as a shared body of water and foundation for our research. We pragmatically chose a rectangular map cutout, on which population numbers were charted for eight survey years from 1300 to 2015 . The maps in this article have been compiled on the basis of datasets that were produced as part of the research project "Ranking cities around the North Sea," and that were made possible in part with grants from DANS and 4TU (van Mil \& Rutte, 2020a, 2020b). In addition to including a series of maps $(1300,1500,1700,1850,1900$, $1950,1990,2015)$ that allowed us to rank cities based on population size, we include a series of three maps in which the population numbers are combined with flows (infrastructures) and boundaries (political borders) in 1500,1900 , and 2015 . These maps give us a better understanding of the porosity of port cities - the movements of people and goods around the North Sea and political forces behind them.

\subsection{Working with Population Data from 1300 to 2015}

Since the introduction of geographic information systems (GIS), online mapping interfaces, and available digital data, it has become easier to create detailed maps from a huge number of statistical datasets. Although creating and interpreting maps requires some technical spatial knowledge, more people than ever can produce them, relying on a series of well-established cartographic and statistical principles (O'Brien \& Cheshire, 2016). This is especially the case when the maps concern contemporary social, political, or demographic data from a single national state. Finding-or building - a reliable dataset and mapping long-term urbanization patterns in a region that includes multiple political boundaries, however, requires more specialized knowledge and labor to process datasets to obtain meaningful and reliable results. We will explain some of the important decisions we needed to make concerning definitions and criteria when we were selecting and interpreting data and data sources, as well as when we were classifying and unifying data in the context of porosity.

In recent decades, several extensive and valuable global demographic studies that take a long-term perspective have been published by Chandler (1987) and Modelski (2003). Concerning Europe, the demographical studies of De Vries (1984), Bairoch et al. (1988), Terlouw (1996), Pinol (2003), and Rutte and Abrahamse (2016) should be mentioned. The two global studies, as well as the European studies by De Vries (1984) and Bairoch et al. (1988) provided demographic data in tabular form with an extensive account of the sources, definitions, and interpretations used, but these studies are limited in terms of time frame: Chandler's (1987) study stops at 1975 , and is the only one to make it to the twentieth century. A disadvantage of the other three studies is that they provided only a series of demographical maps without the underlying data itself being visible or accessible as spatial datasets. Until recently, the only spatially explicit data on urban populations with global coverage was the United Nations World Urbanization Prospects (Desa, 2014). This free available dataset is considered the most authoritative source of global urban population data and provides information on urban populations for major urban agglomerations around the world. However, these data are only available starting in 1950 (Reba, et al., 2016). In 2015, the Yale School of Forestry \& Environmental Studies published the first spatially explicit dataset of urban settlements from a long-term perspective, 3700 BC to AD 2000, by digitizing, transcribing, and geocoding the historical, archaeological, and census-based urban population data of Chandler and Modelski (Reba et al., 2016).

With these primary sources as a starting point, we have developed and refined a dataset for the North Sea region (the Netherlands, Belgium, and parts of the United Kingdom, Norway, Denmark, Germany, and France) for eight moments in history, starting in 1300, 
and we use steps of 200 years to capture major social, geo-political, and economic changes. We add more detailed information through smaller steps of 25 to 50 years; these are represented through the years 1850 , $1900,1950,1990$, and 2015 . Identifying the appropriate time period to represent in a map in relation to space allows us to capture key changes and patterns, but a particular time period may mean one thing for one continent or country, and something else entirely for another. Selecting time periods for a region that crosses several national borders, is therefore difficult. We tried to overcome restraints in the availability of data to allow a view from the sea. Based on the selected scale and time periods, we framed the data and added missing numbers of cities and reference years on the basis of available data from national or regional publications and open access databases including results of national censuses and the Eurostat Regional Yearbook by the European Commission (Kotzeva, 2019). For each reference year we selected only the largest cities in terms of population, each with its own minimum threshold: In 1300 the minimum is 3,000 inhabitants; in 1500 it is 5,000; in 1700 it is 7,000; and so on, with a maximum of about 100 cities per reference year. Chandler (1987), De Vries (1984), and Bairoch et al. (1988) relate the threshold to urbanity or the number of urban inhabitants, but as argued below, definitions of each differ widely. By using a maximum of the 100 largest cities per reference year it is possible to provide insight into shifts in the urbanization patterns around the North Sea. After collecting and processing the population numbers, we have harmonized the data and where necessary spatialized the dataset by providing latitude and longitude values.

In selecting data, before establishing municipal administrative boundaries, it is important to define 'city' and 'city population,' especially in the periods up to 1850 . There is a wide variation in definitions of urbanity and it is well established that 'urban' is a multi-dimensional concept, and that the city is defined in myriad ways by different disciplines and research communities (Reba et al., 2016). Chandler for example, defines a city as "urban area including suburbs lying outside of the municipal area, and omitting farmland lying within the municipality" (Chandler, 1987, p. 1). Bairoch et al. (1988) aimed to improve Chandler's population estimates by also taking into consideration the land type within city walls (commercial, residential, gardens, or grazing), uninhabitable space within buildings, and the density of occupations, and suggests increasing Chandler's estimate of European city values by 15 percent (Bairoch et al., 1988; Reba, et al., 2016). In modern times, most scientists and disciplines define an urban area using administrative or political boundaries, but there are national differences in how municipal boundaries are determined. For instance, the boundaries of German urban municipalities are much wider than those of Dutch municipalities. Moreover, cities and their boundaries are constantly changing. Between 1900 and 1950, for example, the population of Hamburg increased significantly, not only because of urban growth but because Altona was incorporated by Hamburg in 1938. Another example of a change in the pattern, which is not necessarily related to urbanization, is Wuppertal. This German city was created in 1929 through the merger of several villages and towns, including Elberfeld and Barmen, which until 1900 were among the cities with more than 50,000 inhabitants. Most municipal border changes were made in the second half of the 20th century. In the Netherlands, the number of municipalities fell from over 1,000 in 1950 to just over 500 in 2000. In England, the Local Government Act of 1972 revised all administrative boundaries. The reclassification of cities and municipal boundaries complicates the comparison of census results between 1950, 1990, and 2015.

Another critical issue concerning selecting and interpreting data is availability. The further back in time, the more limited the available data. The data that do exist are often not comparable from one city to another. Given that historical sources are often incomplete, the quality of the data is uneven and often does not permit full understanding or comparison. Translating historical developments into maps involves numerous questions about which dates to choose. A date that is meaningful in one country may have less relevance for another, making the choice of a date for comparative research particularly difficult (Hein \& van Mil, 2019). Population censuses and other methods of measuring populations record numbers in intervals. These intervals do not always run parallel to the chosen reference years; circumstances such as war, natural disaster, and political agitation can disrupt the interval. For reference year, 1850 for example, the results of the census from 1851 are the most accurate for French and English cities; in Belgium the most accurate would be the results of 1846; for Germany, 1849, and for Denmark, 1845 or 1855 . Estimates are therefore inevitable. To avoid a semblance of precision and yet show a reliable pattern, the population numbers are rounded to thousands. Additionally, we attempt to crosscheck these demographic factors, definitions, and methods when possible. Undoubtedly, errors remain, and a more rigorous process would strengthen the values in the dataset. Unlike some other demographic data, such as Chandler's digital dataset (Reba et al., 2016), we did not add a reliability rating by including a number for certainty to the dataset.

To classify data for mapping, it is crucial to decide both the number of classes and the method for breaking data into ranges. In classifying the population numbers, we chose to distinguish six classes, which reduces the chance of data generalization and increases readability. Generalized data is easy to read and remember but may gloss over some important aspects of data and create artificial geographic patterns by lumping together many places that are in fact quite different. Too many classes would increase the risk of map reading errors because more variation in size means a smaller distinction in classes, which is more difficult to identify. GIS allows 
you to choose from a variety of preset classification methods, including Equal Interval, Quantile (equal numbers), and the Jenks (1967) natural breaks. These classification methods did not adequately differentiate the required spatial patterns, mainly because the outliersin this case the large cities with high population numbers such as London, Hamburg, and Brussels-occupied the three highest categories, while the majority of the cities - with low population numbers such as Cambridge, Oslo, and The Hague-were combined into the lowest class. Therefore, a manual method was developed, based on a modified Jenks classification. Jenks natural breaks is a commonly used method and a kind of optimal classification that finds class breaks that (for a given number of categories) will minimize within-class variance and maximize between-class differences (Jenks, 1967). A disadvantage of this approach is that each dataset generates a unique classification solution. Since we make a series of maps that show developments and changes within the population pattern over time, it is important that the classification can be applied to all maps and that reference years match. The Jenks classification system was modified to include more categories for cities with a lower population and fewer categories for high populations and to align the categories of the reference years from 1300 to 2015 . Between 1300 and 1500, for example, the population remains almost the same: Only the minimum threshold and the highest population differ. With the Jenks classification method, the breaks would be unequal, but are kept the same. To visualize the increase in population over time, the size of the symbols has also been manually adjusted. However, the differences in population from 1300 to 2015 are too big for a true continuous series. Moreover, the aim of this study is to show shifts in urbanization patterns and not the development of population over time (see Figure 1).

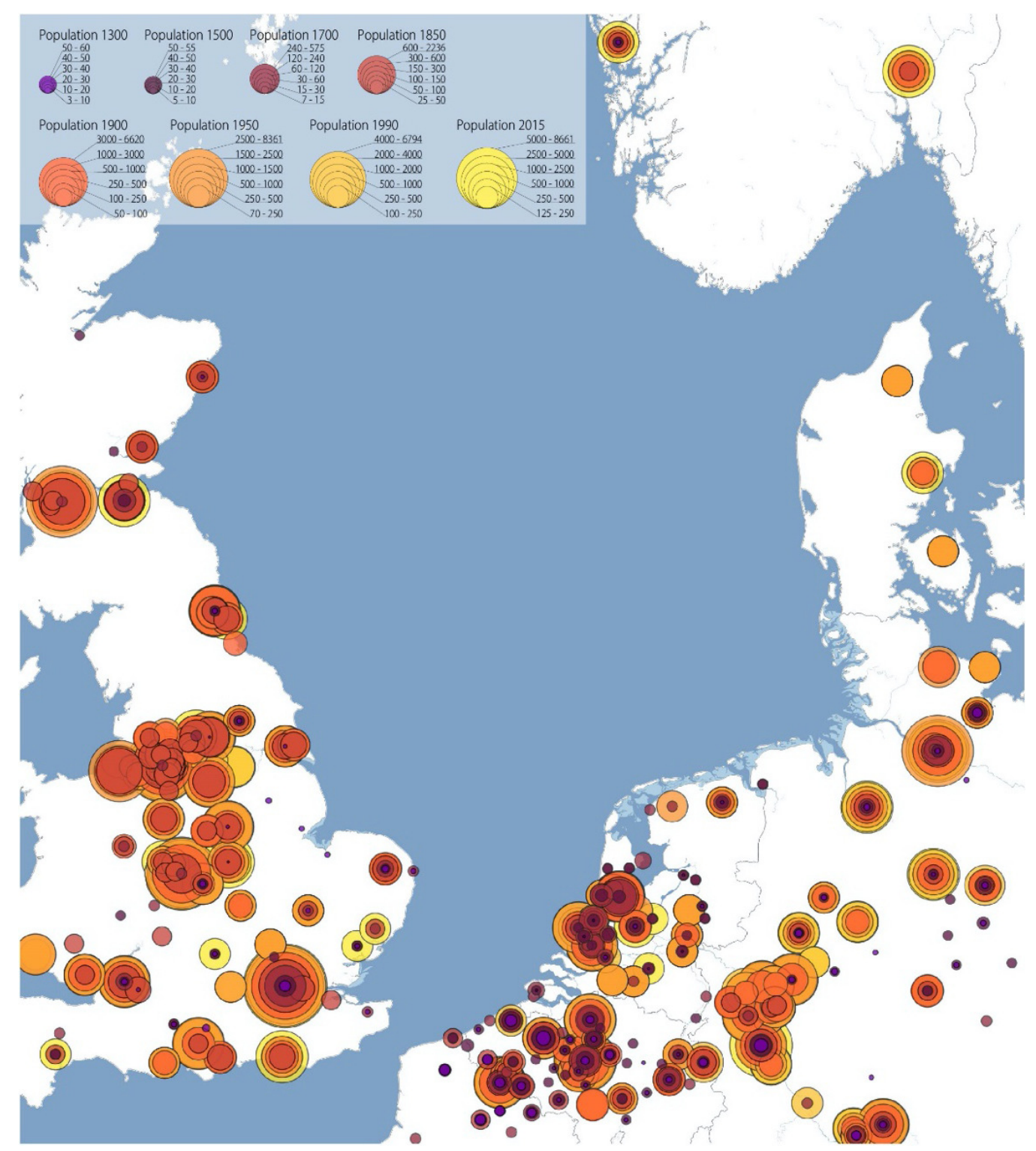

Figure 1. The result of mapping and ranking population numbers in eight survey years. Map by Yvonne van Mil. Source: van Mil and Rutte (2020a, 2020b). 


\subsection{Working with Historical Maps and Digital Datasets about Infrastructure and Political Boundaries}

Finding-or building-reliable data sets is one of the biggest challenges in research. It requires the necessary knowledge and labor to process datasets to obtain meaningful and reliable results. Historical maps and existing datasets imply definitions and decisions; they reflect local particularities and historical choices that may already shape answers. In addition, the effectiveness of a map is a result of selectivity, but before selecting or determining data, it is important to acknowledge the purpose and the historical and social context of the maps in order to select the necessary information (Hein $\&$ van Mil, 2019). To estimate the reliability of a map, it is important to know the function: Who is the cartographer or client and what was the purpose of the map? A map is first and foremost a tool of communication, and to understand a map we need to know both the supply side (the maker) and the demand side (the client). We can only understand maps if we know what the cartographer wanted to show, to whom, and why. The purpose of the map determines the scale, the reliability, implementation, and content (Renes, 2016). As Segal (2020) shows in his article "Flow Mapping through the Times," infrastructures-especially canals and railwayswere used to display a country's sophistication and prosperity: "Movement and flows became [from the mid19th century] the signifiers of cultural and scientific progress, while a lack of movement was a sign of retardation" (Segal, 2020, p. 92). Topographical and thematic maps from the 19th to mid-20th century support this assumption; railways and canals are the most or sometimes the only indicated infrastructures on maps, and are represented as the drivers of flows of people and goods. This complicates the mapping of important infrastructures in history. For the reference years 1500, 1900, and 2015, a first attempt was made to map the main infrastructures over water, land, and rail for the North Sea region, and combine them with political boundaries. In this section some difficulties and decisions are explained in more detail.

Infrastructure usually refers to the total of facilities such as railways, airports, ports, cabling, sewerage, and road networks. In this article, by 'infrastructure' we mean physical connections over land, water, and rail, as connections facilitating flows of goods and people. Roads enable flows, but they also restrict them in the sense that they define the routes flows can follow and thus where it is possible to go (Edwards, 2003). Flows of goods can mean economic prosperity and urban growth. Infrastructure, especially the construction of new canals, land, and railroads, has therefore been the cause of conflict between cities and regions for ages (De Pater, 2009). In 1500, waterways were the main transport routes. River access was one of the main reasons for the emergence of urban centers. For centuries waterways have been dammed and deepened, and new water- ways have been constructed (canals). After 1800, country roads and railways increasingly took over the transport of people and goods. However, water transport remained important, especially the newly constructed and modernized canals. For the reference year 1500 , we only show waterways and possible routes-flows over land. For the other two reference years, we show roads, waterways, and railways.

The roads and railways shown on the map are primary routes, meaning transport connections on land between major cities and industrial areas of (inter)national importance. On the map of 1500 and 1900 , the land roads are not by definition the primary, or most important routes or flows: Formal hierarchy in roads has only existed since the 19th century. The French government was the first to introduce a road network that distinguished between different road types serving different purposes. At the top of the hierarchy were the Grandes Routes, which started in Paris and continued to a major city or seaport or to an international border (Blond, 2013). At the beginning of the 19th century, Napoleon Bonaparte continued the French hierarchical system of roads (Routes Impériales) throughout the French Empire, including Belgium and the Netherlands (Schipper, 2008). Since the introduction of motorized transport, a hierarchy in roads was standardized at a national level and after 1950 on a European level (E-road and TEN-T network).

The first step in the map-making process is finding reliable sources that accurately reflect the most recent reference year. Because we are examining different geographical regions around the North Sea, it has been important to find global or continental GIS datasets that cover several national states with sufficient spatial resolution to analyze and compare the regions in a consistent and systematic way. National and regional data may be more detailed and accurate, but is often not freely accessible and each dataset has its own definitions and criteria, which makes combining and comparing difficult (Hein \& van Mil, 2019). As a starting point for the dataset on infrastructure we used the EuroGlobalMap from Eurogeographics (2017). After selecting, adjusting, and preparing the GIS datasets to obtain the required maps for reference year 2015, new data must be generated for the years 1900 and 1500 . For this, we have relied on national sources and historical maps. For 1900, changes in the infrastructure and landscape can be mapped on the basis of regularly updated national topographic maps, such as Ordnance Survey maps, supplemented with thematic maps. For 1500, we used two studies on land routes in the Netherlands, one by Horsten (2005) and one by Kosian et al. (2016), supplemented with indications and assumptions based on literature, national topographical maps, and logic. For the waterways in 1500, we used the Stedenatlas Jacob van Deventer (Rutte \& Vannieuwenhuyze, 2018) and London: The Illustrated History (Ross \& Clark, 2008, p. 68). The political boundaries are obtained from Euratlas (n.d.). 


\section{Description and Exploration of Urbanization Patterns and Shifts}

\subsection{0: Foundations}

The largest concentration of cities and the center of economic gravity was found in the principalities of the Southern Netherlands: Flanders, Brabant, Artois, Hainaut, and Liège (see Figure 2). This is also where seven of the ten largest cities in 1300 were located: Ghent, Bruges, Ypres, Saint-Omer, Lille, Arras, and Douai. In addition, London, Cologne, and Lübeck were among the largest ten. Both the largest cities and the other cities in the Southern Netherlands were connected to the North Sea by navigable water: The rivers Scheldt, Lys, IJzer, Aa, Meuse, and tributaries. In the Northern Netherlands, cities such as Dordrecht, Nijmegen, and Deventer that were situated on the major rivers Rhine, Meuse, and IJssel, also flowed into the North Sea. Delft and Leiden lay along a trade route through Holland, a crucial north-south water link for northwest European trade.
The cities in the German countries, apart from Cologne and Lübeck, for example Mainz and Bremen, were more dispersed and were spread across several principalities. Here we find a good example of porosity in the Middle Ages: The sea with the flows was important, the boundaries were not. As in the Low Countries, rivers flowing into the North Sea were of great importance: In addition to the Rhine, there were the Elbe and the Weser. In England, the orientation of many towns towards the North Sea is also striking. Great Yarmouth is the only one close to the coast, the others are connected to the North Sea by rivers and include London and Oxford via the Thames, Norwich like Great Yarmouth via the Yare, Boston and Lincoln via the Witham, and Hull and York via the Humber-Ouse. In Scandinavia only Bergen is on the map.

During the time of city formation - the 11th-14th centuries-hundreds of cities sprang up around the North Sea (Verhulst, 1999). Only a limited number were important and appeared on the map: These were the cities with a favorable location and a good water

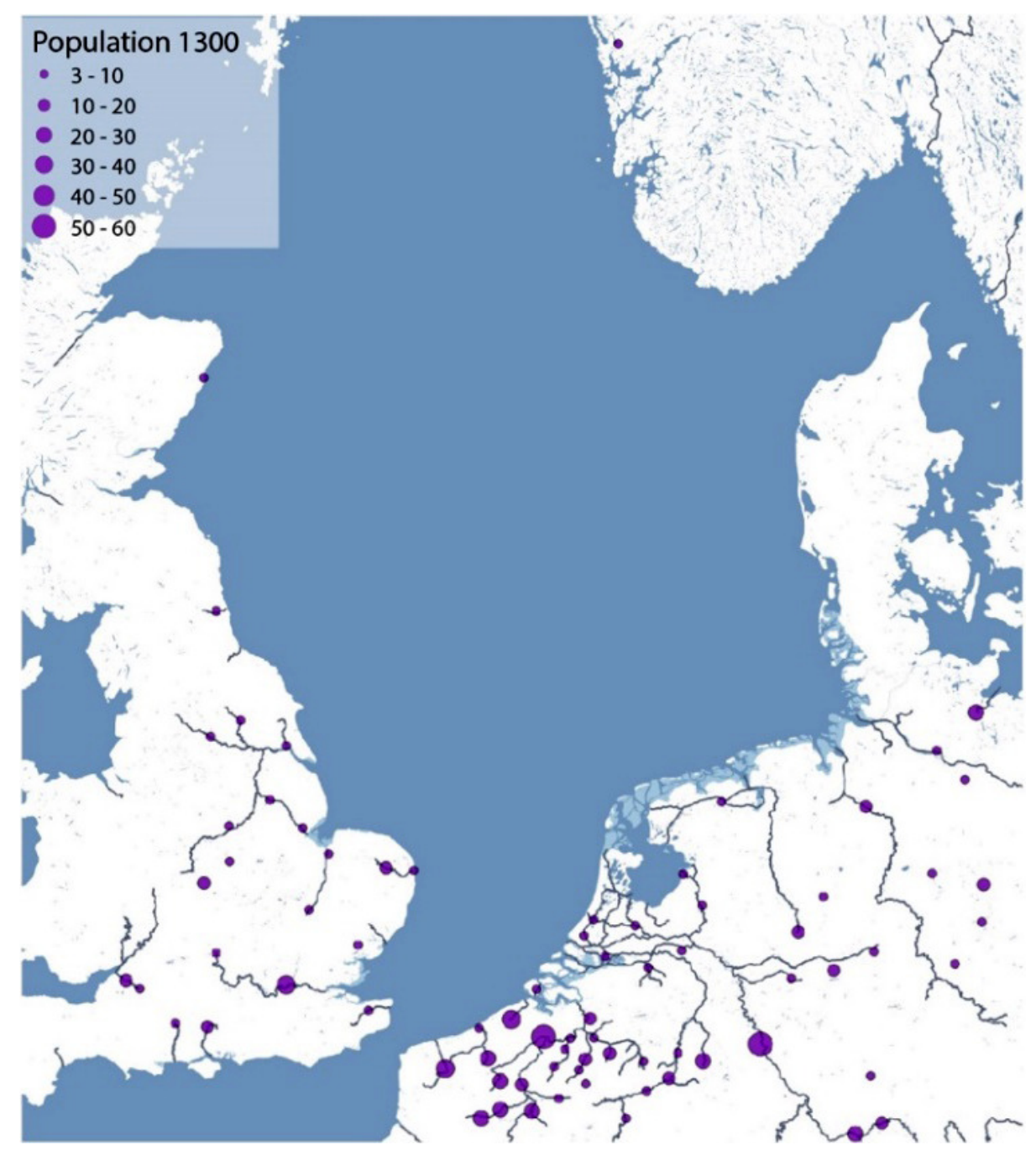

Figure 2. Cities around the North Sea area with the largest population in 1300, combined with main water courses. Map by Yvonne van Mil. Source: van Mil and Rutte (2020a, 2020b). 
connection to the North Sea. Intensive contacts existed between these port cities (Ayers, 2016, pp. 33-70). Moreover, these cities, especially the larger ones, were hubs between the cities in the hinterland and trade flows across the North Sea. The high concentration of cities in the Southern Netherlands is probably due to their central location in relation to the German and French hinterland as well as the North Sea and England and, furthermore, to the fertile agricultural land that was easily accessible from the rivers. This was an area where a large group of cities could flourish, together forming a solid economic system (Boone, 2013). The pattern formed by the cities in the Southern Netherlands also had to do with the fact that, in addition to waterways, there were landbased trade routes, via Cologne, between the Rhineland and the Flemish coastal area on the North Sea (Verhulst, 1996). It is striking that the largest concentration of cities in the Southern Netherlands and the cities in the German lands, in contrast to the kingdom of England, are situated in a fragmented area with many political boundaries, governed by many lords, dukes, counts, and bishops, who did not always seem able to exercise much power. This phenomenon is characteristic of the Low Countries and the German countries, especially during the 12th-13th centuries: the German emperor, who was officially in charge, had little authority. Some lords, such as the Counts of Flanders, the archbishops of Cologne, the bishops of Munster, the Dukes of Brabant, and the Counts of Holland knew how to take advantage of this, but it was mainly the inhabitants of the cities who knew how to benefit: Burghers, merchants, and skippers became powerful (Blockmans, 2010, pp. 23-161).

\subsection{0: Crossroads}

Compared to 1300, four striking trends can be observed in 1500 (see Figure 3): 1) An increased concentration of cities in the Southern Netherlands, but also some shifts, such as Antwerp, Mechelen, and Brussels emerging at the expense of Saint-Omer, Ypres, and Douai; 2) An increase in the number of cities in the Northern Netherlands, especially in the principality of Holland and along the river IJssel, for example Haarlem, Amsterdam, and Kampen; 3) A decrease in the number of cities in England as well as a contraction of those remaining; and 4) Little change in the German countries, where Cologne remained the largest city.

In 1500, the historical sources and available data make it possible to represent land trade flows on the map (see Figure 4). For example, the connection between the distribution pattern of the cities in the Southern Netherlands and the important routes to Cologne and the Rhineland come into focus. It also becomes clear that in the Low Countries along the North Sea, waterways were the primary infrastructure, while the German countries depended on overland routes for east-west connections. In England, on the other hand, the rivers to the North Sea were decisive for east-west trade. The north-south connections were overland. Ostensibly, these land routes run partly from nowhere to nowhere, but that is because cities smaller than the largest 100 in 1500 are missing from the map. Proportionally, cities in England were hardest hit by the plague, which claimed many victims in Europe in the mid-14th century (Pounds, 1990, pp. 187-209). The Northern Netherlands
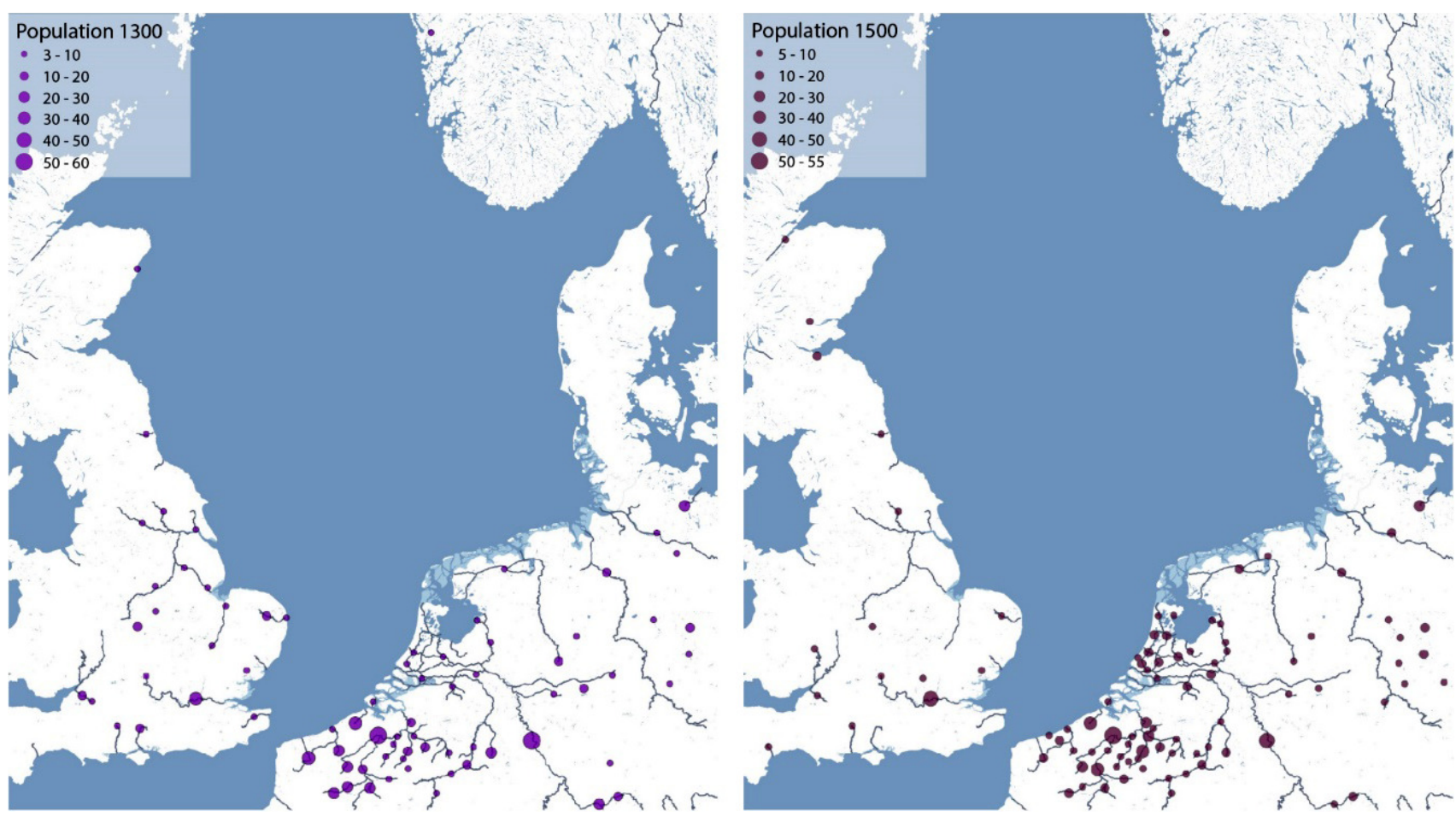

Figure 3. Cities around the North Sea area with the largest populations in 1300 and 1500, combined with the main water courses. Map by Yvonne van Mil. Source: van Mil and Rutte (2020a, 2020b). 


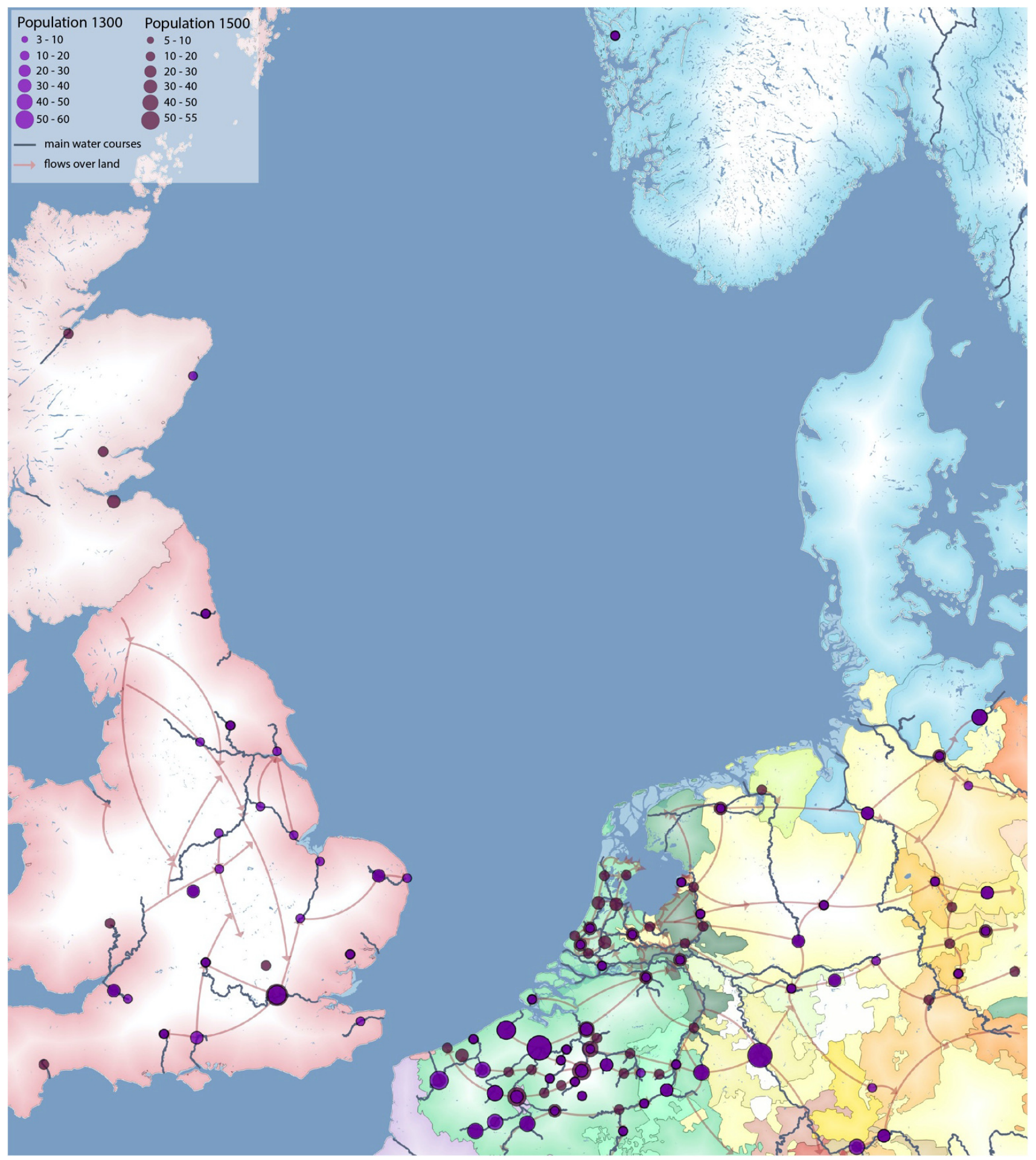

Figure 4. Cities around the North Sea area with the largest populations in 1300 and 1500, combined with political boundaries and flows of goods and people over land and water in 1500. Map by Yvonne van Mil. Source: van Mil and Rutte (2020a, 2020b).

in particular seems to have suffered less from the plague: The number of towns increased between 1300 and 1500, perhaps even thanks to the demographic and economic decline in England. In a broader perspective, the developments in the Northern Netherlands during the 14th-15th centuries were exceptional, because in large parts of Western Europe this was an era of decline or contraction.
In this period, the transit function of the port cities in Holland became more important (Brand, 2011). Its location at the junction of the trade flows by water from the Rhineland to the North Sea and from the Baltic to the south was particularly favorable. By 1500, much of the Low Countries was in the hands of the Burgundian princes, but it will be shown below that the remarkable 
fragmented political geography benefiting cities and citizens did not end there.

\subsection{0: Shifts}

Comparing the map of 1700 with that of 1500 , four striking trends can be identified (see Figure 5): 1) The concentration of largest cities shifted from the Southern Netherlands to the Northern Netherlands, with the center of economic gravity becoming the province of Holland, with Amsterdam as its largest city, accompanied by a group of other large cities including Leiden, Haarlem, Delft, Rotterdam, Gouda, and Dordrecht; 2) There was a decline in the number of cities in the Southern Netherlands and a contraction of the remaining ones, particularly of Ghent, apart from Brussels, which grew; 3) While Bremen and Emden emerged during this period, there was a decline in the number of cities in the German countries, apart from Cologne, which remained important, and Hamburg, which grew strongly; and 4) The number of cities in England increased and London and Edinburgh became much larger.

The shift from the Southern Netherlands to the Northern Netherlands is inextricably linked to political boundaries and the Eighty Years' War (see Figure 6). The cities and provinces of the young Dutch Republic fought to free themselves from Spanish rule and gain political independence, but above all economic freedom, which brought about an enormous flow of people and trade. In 1585, the Scheldt was blocked by the Dutch rebels and Antwerp fell into Spanish hands, as did the rest of the Southern Netherlands, which were under the yoke of the Spanish rulers. Many people from Flanders, Brabant, Artois, and Hainaut fled north, particularly to cities in Holland, such as Rotterdam, Delft, Leiden, and Haarlem. These cities formed a tight economic system together with the most important city, Amsterdam, which took over the role of world seaport from Antwerp (Lesger, 1993). The Republic experienced a Golden Age as a seafaring nation. This attracted many immigrants from the German countries too, both from the cities and the countryside (De Vries, 1984, pp. 151-172; Terlouw, 2009). Cities in the hinterland stagnated, but a limited number of port cities favorably situated in relation to the North Sea, experienced golden times during the 17th century: Hamburg, Bremen, Emden, Edinburgh, and London, because these were sea-minded, porous port cities, entrance gates to the hinterland, like Amsterdam and Rotterdam. In the late 16th century and during the 17th century, Holland became the economic heart of Europe largely because of a number of economic and political-administrative shifts in the center of gravity, not only from the Southern to the Northern Netherlands but also a shift from lords to burghers. We saw earlier that in the late Middle Ages the burghers in the towns gained in influence at the expense of rulers like the Counts of Flanders or the Dukes of Brabant. In the 15th century, the Dukes of Burgundy took over in the Low Countries, which subsequently, in the 16th century, under Emperor Charles $\mathrm{V}$ and his son and successor Philip II, were absorbed into the Spanish-Habsburg Empire. However, during the Eighty Years' War, the urban
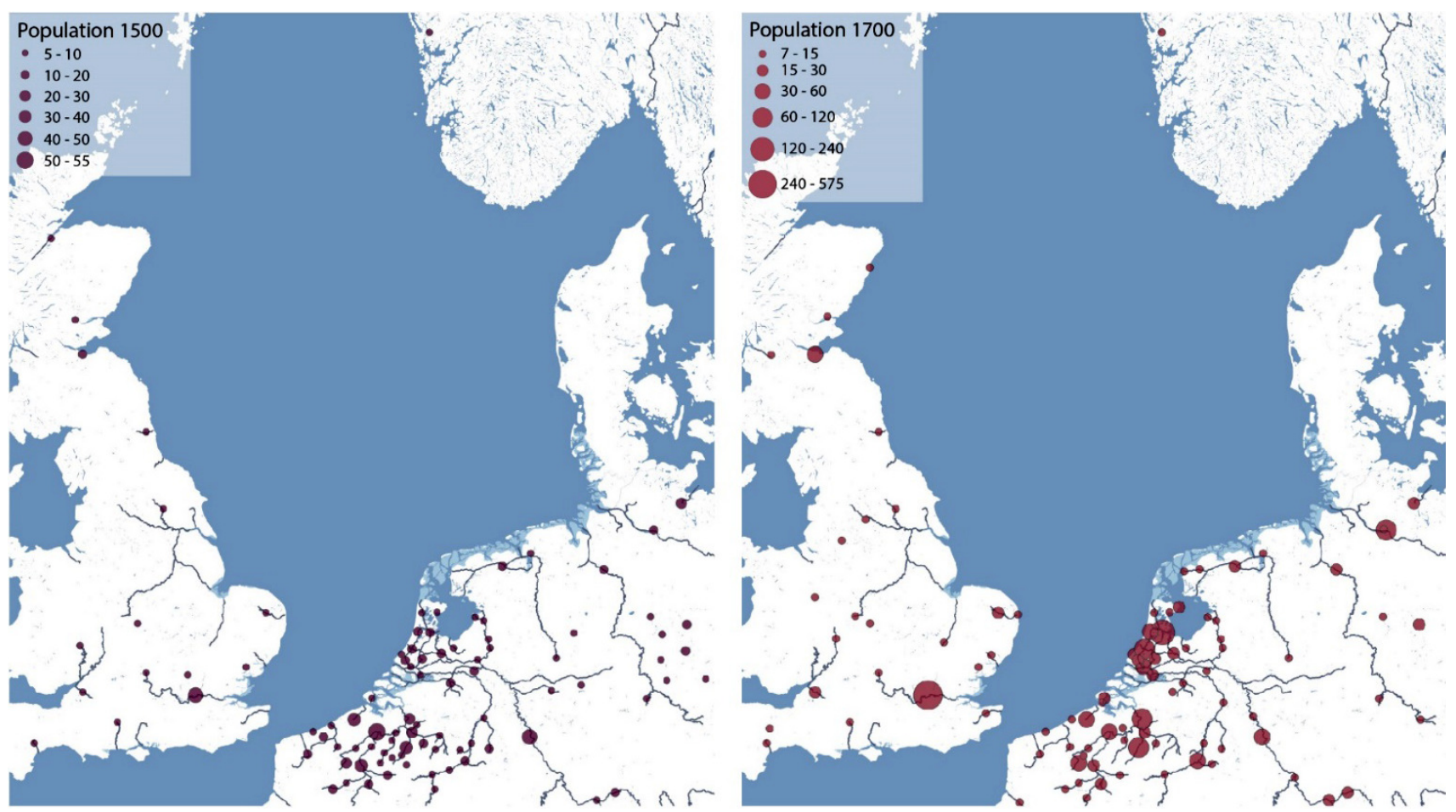

Figure 5. Cities around the North Sea area with the largest populations in 1500 and 1700, combined with main water courses. Map by Yvonne van Mil. Source: van Mil and Rutte (2020a, 2020b). 


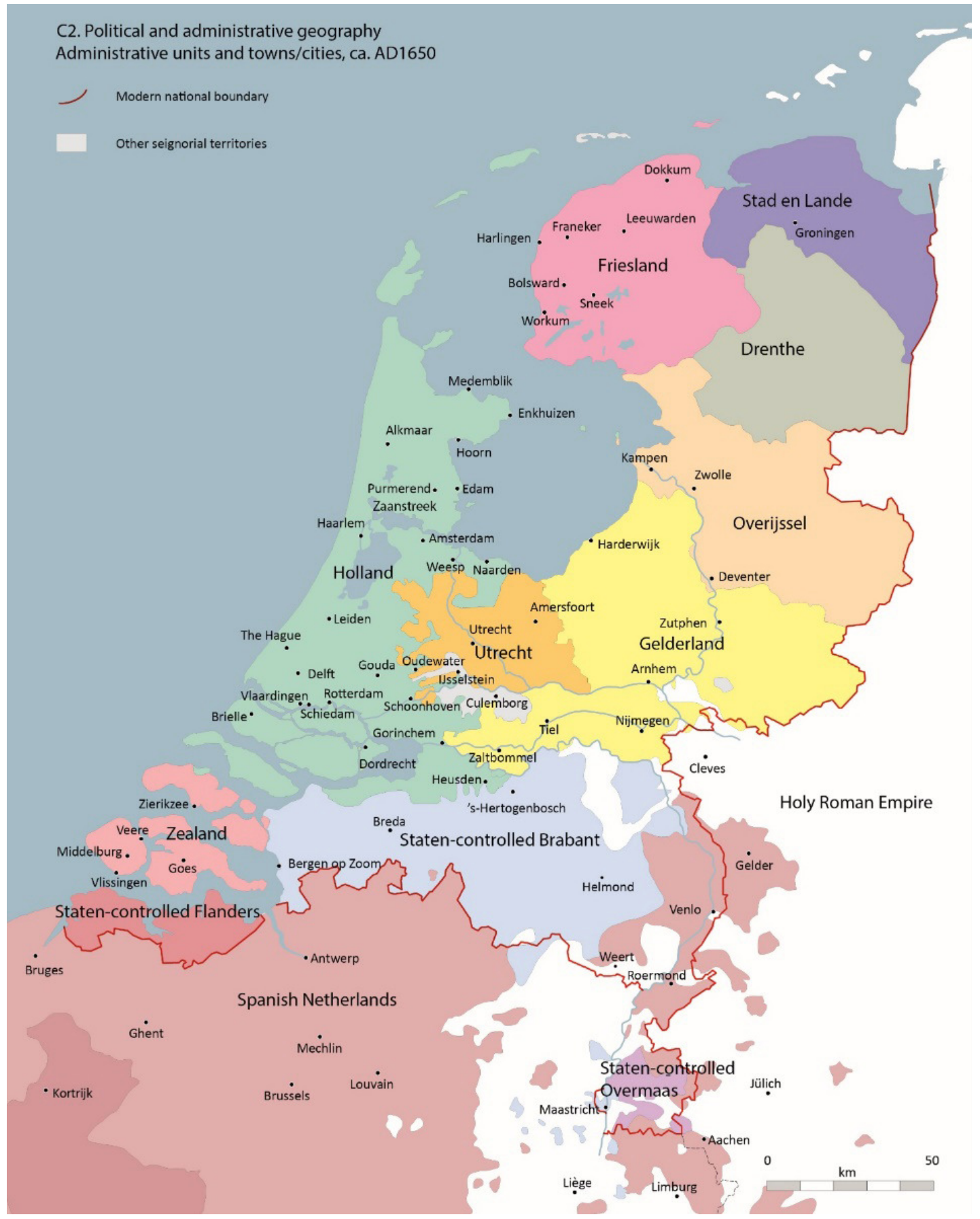

Figure 6. Political and administrative boundaries in the Netherlands, ca. 1650. Source: Rutte and Abrahamse (2016).

citizenry in the fragmented area of the seven provinces of the Dutch Republic began to act with increasing independence while the economies of the cities in Holland flourished (Rutte \& Abrahamse, 2016, pp. 188-197).

\subsection{0: Changes}

In the 150 years between 1700 and 1850, six striking trends occurred (see Figure 7): 1) The concentration of the largest cities shifted from the Northern Netherlands to England, with a new center of economic activity blossoming in the Midlands, where there were rapidly growing industrial cities, the largest being Manchester, Birmingham, Leeds, and Sheffield; 2) London and Edinburgh continued to grow; 3) The North Sea ports in the United Kingdom declined in relation to the Atlantic ports of Glasgow, Liverpool, and Bristol, although Newcastle, Hull and, as said, London, also experienced strong growth; 4) Cities in the former Dutch Republic (since 1815, the Kingdom of the Netherlands) sharply declined and cities in the provinces of North-Holland and South-Holland, including Leiden, Delft, and Gouda, also contracted; 5) The number of cities increased in northern France, the south of the young kingdom of Belgium, 

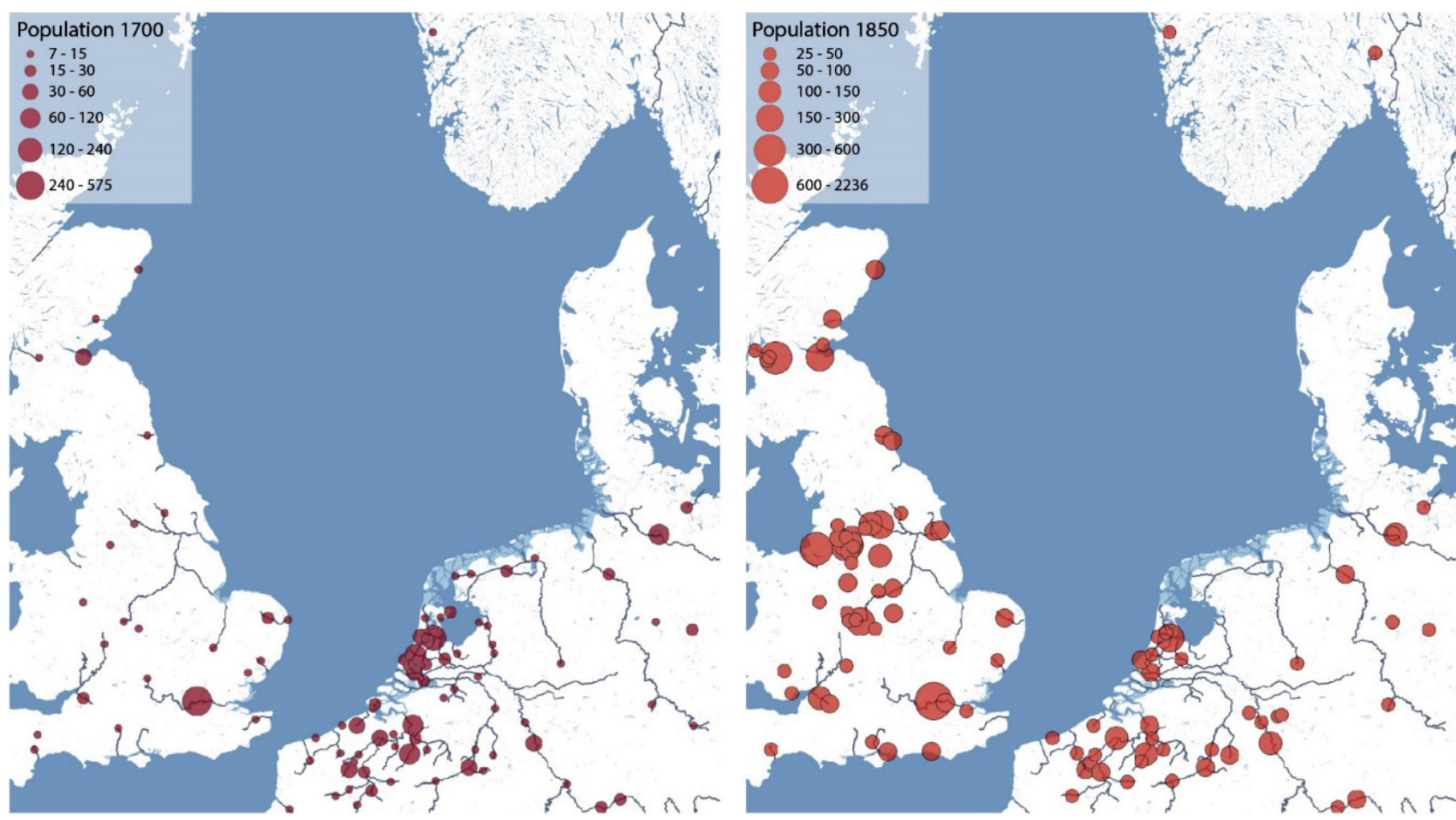

Figure 7. Cities around the North Sea area with the largest populations in 1700 and 1850, combined with main water courses. Map by Yvonne van Mil. Source: van Mil and Rutte (2020a, 2020b).

and around Liège; and 6) The Ruhrgebiet also saw new cities emerge.

During the Dutch Golden Age, the administration of the Republic was characterized by a combination of seven united provinces, a group of powerful cities, stadholders, and so-called raadspensionarissen, and during the 18th and 19th centuries the British Empire developed into a world power (see Figure 8). London was both the capital of the empire and a major port. In addition to a British hegemony at sea and overseas territories, the Industrial Revolution during the second half of the 18th century was decisive. Raw materials including coal and ores, equipment like steam engines and blast furnaces, and a new infrastructure of canals and railroads brought about major changes (Hohenberg \& Lees, 1995, pp. 179-214). Industrialization led to an unprecedented increase in scale, especially in the Midlands, where necessary raw materials were mined. Consequently, the seaports on the west coast of the United Kingdom experienced great growth. On the continent, too, industrialization took off in the vicinity of coal basins, to which the new infrastructure of canals and railroads was adapted. This transformation took place during the early 19th century in the border region of France and Belgium, around Liège, and in the Ruhrgebiet. For the Ruhrgebiet, the Rhine was the main transport artery. Rotterdam became an important transhipment port. Industrialization enhanced the importance of North Sea ports as links in the transport chains of raw materials and other products. At the same time, the significance of the North Sea as a link between the surround- ing countries and as a guiding factor for the patterns of cities seems to have diminished during this time, not only because of the new infrastructure of railroads, but also because industrialization was largely determined by the presence of raw materials. Undoubtedly, the large sphere of influence of world powers such as the British Empire and the formation of nation-states also played a role in this.

\subsection{0-2015: Consolidation}

In 1900 , the trends that came into view in 1850 continued (see Figure 9). After a long period of stagnation, in the late 19th century cities in the Netherlands became industrialized and began to grow. This happened much later than in the Midlands, northern France, Belgium, and the Ruhrgebiet. The seaports of Hamburg, Antwerp, Rotterdam, Newcastle, Glasgow, and Liverpool also grew rapidly. Between 1900 and 1950, the population of the cities that were already large in 1900 rose sharply. And finally, some cities in Denmark appear on the map, in addition to Bergen and Oslo in Norway. These developments result in a more even distribution pattern of cities and not one but several centers of economic gravity. However, by 1990, many cities saw their population numbers stagnate or decline, as compared to 1950 . This is particularly the case with the most industrial cities, such as Manchester, Leeds, and Sheffield. Many seaports in the United Kingdom also saw a decrease in population in 1990, particularly Liverpool. In 2015, a modest recovery in population numbers appears to have begun. 


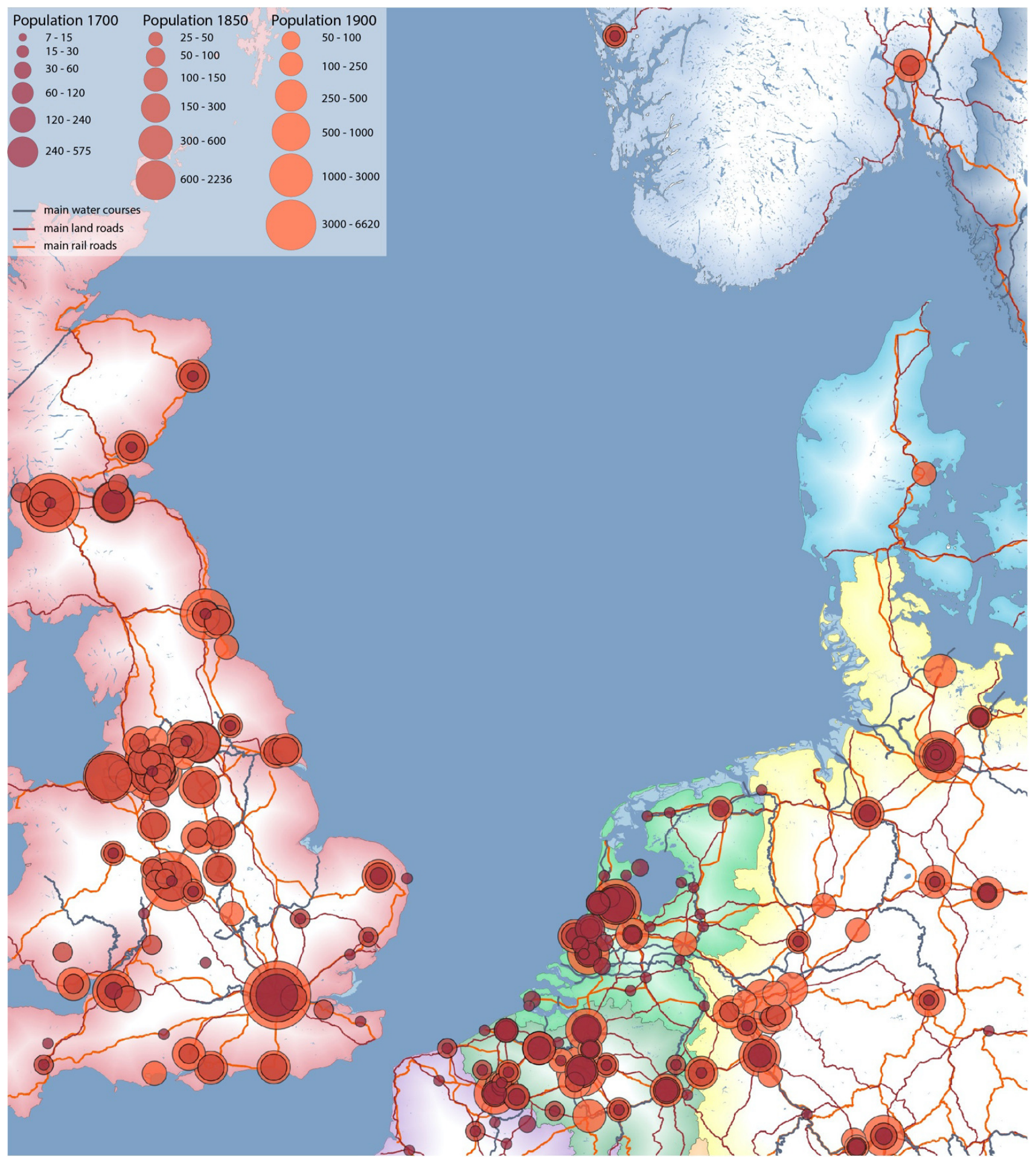

Figure 8. Cities around the North Sea area with the largest populations in 1700, 1850, and 1900, combined with political boundaries and infrastructure over land, rail, and water in 1900. Map by Yvonne van Mil. Source: van Mil and Rutte (2020a, 2020b).

During the 19th century, a major renewal of infrastructure took place with the construction of canals and railways, which connected both existing cities and new industrial cities (Lees \& Lees, 2013). Country roads were improved and renewed, and during the 20th century networks of highways were built. Looking at the maps from 1900-2015 (see Figure 10), it is striking that these infrastructural innovations did not lead to major changes in the distribution pattern of cities during the 20th century. The question is why. Of course, the effects of de-industrialization during the second half of the 20th century should not be underestimated-think of the stagnating or declining populations in many cities, the enormous change in function in industrial cities and port cities, or the differentiation that has occurred. For example, London is no longer an important seaport, 


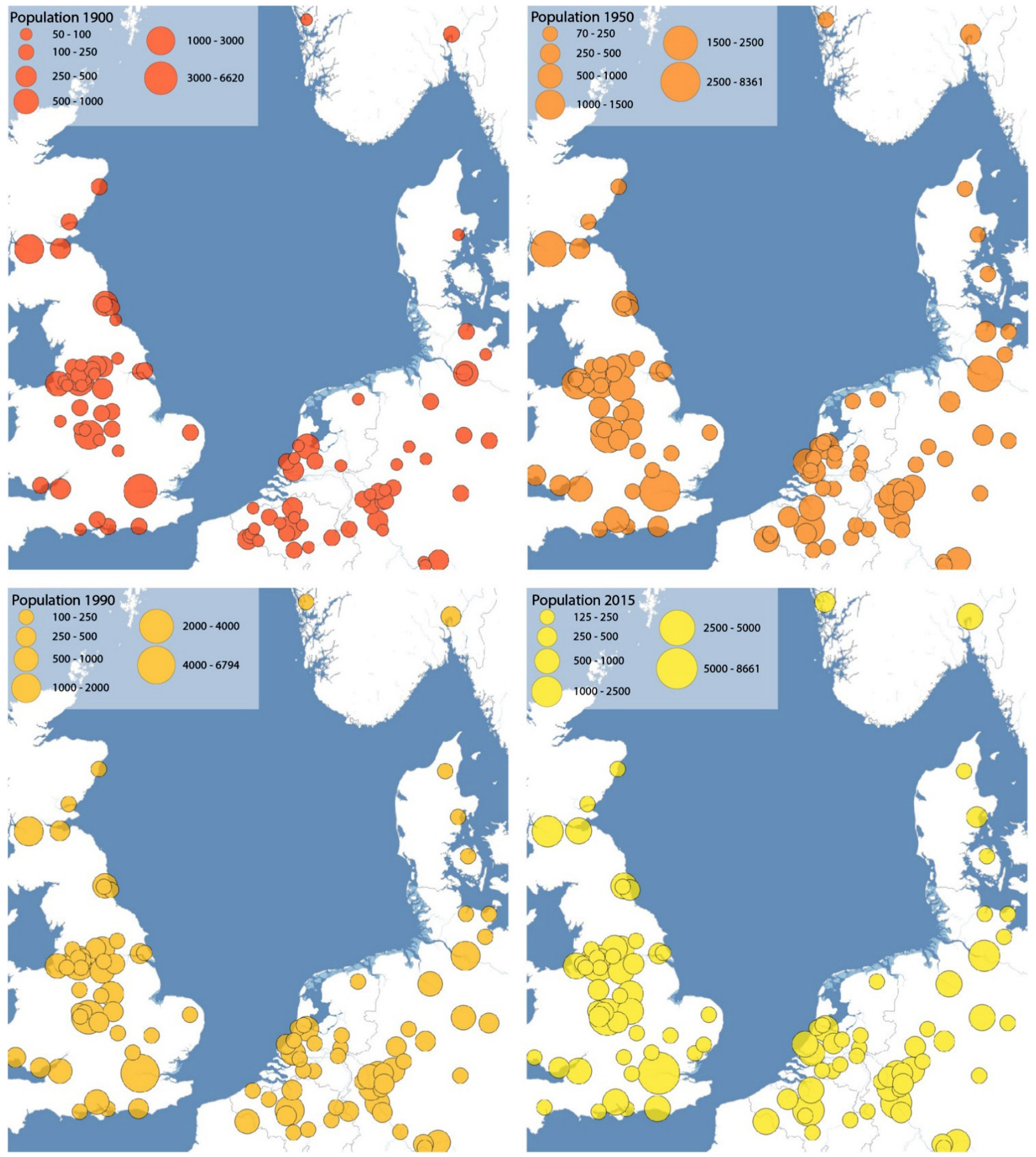

Figure 9. Cities around the North Sea area with the largest populations in 1900, 1950, 1990, and 2015 in thousands. Map by Yvonne van Mil. Source: van Mil and Rutte (2020a, 2020b).

whereas Hamburg, Rotterdam, and Antwerp remain as such, but compared to the shifts we saw in the previous centuries, since 1900 these have been less significant. It is tempting to look for the answer in the rise of national states with strong governments in the 19th and 20th centuries, eventually cooperating in the European Union, but that requires further research. In any case, for the last 100 years or so, national governments have been intensely concerned with the development of their countries, the well-being of their citizens, and with the demographic and economic development of their cities, an unprecedented phenomenon, into which sweeping shifts such as those during the late 16 th-early 17 th or during the 18th century do not fit, since they caused dramatic decline for a long period of time in many cities. 


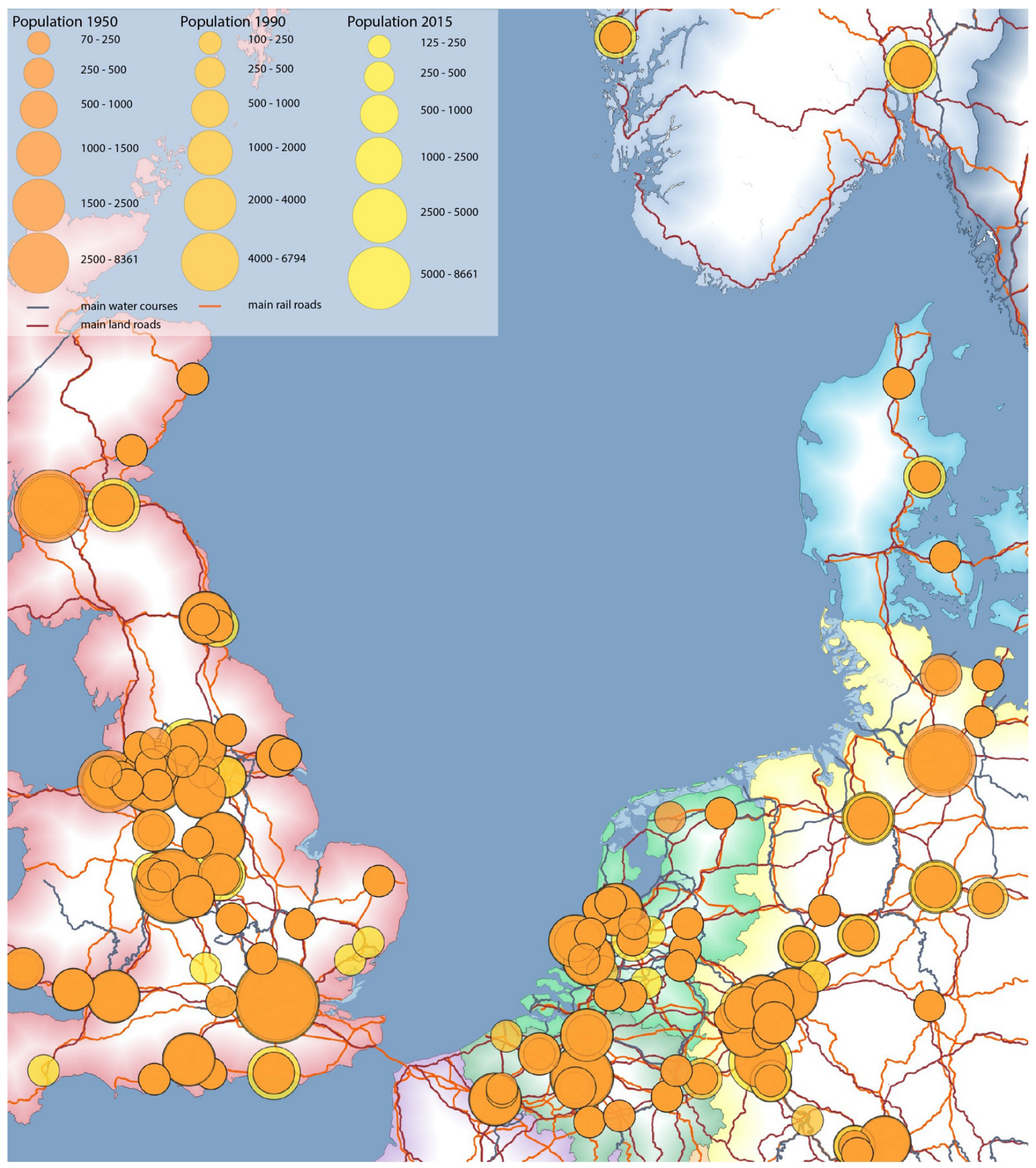

Figure 10. Cities around the North Sea area with the largest populations in 1950, 1990, and 2015, combined with political boundaries and infrastructure over land, rail, and water in 2015. Map: Yvonne van Mil. Source: van Mil and Rutte (2020a, 2020b).

\section{Conclusions}

Taking a bird's eye view of long-term development from 1300 to the present day, the areas around the North Sea seem to have worked like communicating vessels: The Southern Netherlands fall back, the Northern Netherlands rise, Holland falls into decline, England rises.
The porous seaports serve as distribution valves; they connect to the hinterland through canals, rivers, railroads, and motorways, sometimes blocked by national borders. But from the moment industrialization reached the continent, not one, but several centers of economic gravity emerged. The role of the North Sea in the flows between the surrounding areas diminished from that 
point on. Remarkably, until the shift to England, the center of gravity was in politically fragmented areas, where cities and citizens had much influence, while later on, nation-states with national boundaries and influential governments emerged. In addition to the centers of gravity, there are cities like Cologne and Hamburg that have developed steadily from 1300 to the present. It also appears that dynamics vary from area to area. England experienced the most numerous and significant changes over the course of 700 years: It hosted a considerable number of North Sea ports in 1300 , then underwent a prolonged decline due to the plague. It saw renewed prosperity in the 18th century, followed by major growth during industrialization, a new center of gravity in the Midlands, and the increasing importance of the ports on the west coast, eventually followed again by decline.

Contrary to what is often assumed, the current urbanization pattern around the North Sea can best be understood by looking at the long-term development, by examining how this pattern arose and developed over the centuries. Looking no further back than the Industrial Revolution creates a distorted picture. After all, the distribution pattern of cities was largely determined before that time. The basis for today's important port cities, including Hamburg, Amsterdam, Rotterdam, and Antwerp, was laid during the late Middle Ages. Figure 1 shows that many other cities that matter today also go back to that time. Only for two groups of cities was the Industrial Revolution decisive: those in the Midlands and in the Ruhrgebiet, not port cities. To understand the urbanization pattern and the position, function, and meaning of today's important ports and cities around the North Sea, the developments and shifts through time are also crucial. These can be broadly characterized as follows. The foundations for the urbanization pattern around the North Sea were laid before 1500 . The center of economic gravity, with the most important port cities, can be found in a fragmented area, where powerful citizens ensured an intensive exchange of goods beyond the borders; the ports thus served as porous transit centers. Subsequently, the center of economic gravity shifts from the Southern Netherlands to the Northern Netherlands. The Southern Netherlands lost their fragmented freedom and the free Dutch Republic port cities flourished as transit centers. During the 18th century, there were major changes: the center of gravity shifted to the other side of the North Sea, to England, and the character of the economy changed dramatically with the Industrial Revolution. The main port cities were then part of a kingdom, which became the British Empire. From the moment industrialization began in northern France, Belgium, and the Ruhrgebiet at the beginning of the 19th century, the North Sea region has been characterized by different economic centers of gravity, which have persisted despite profound economic changes in the 20th century. Thus, consolidation of the urbanization pattern occurs, to all appearances, due to the intensive involvement of national governments in the development of the cities.
We hope that with this exploratory article we have made it clear that combining, classifying, unifying, and mapping data offers many possibilities for making longterm spatial and social-cultural developments transparent, and useable for different goals. We are aware of the limitations of (historical) maps as a source, as well as maps as scientific evidence. In this study, the maps provide insight into large amounts of spatial data, which make it possible to study and understand urbanization patterns in a Western European context, and a means to communicate by presenting the data in a series of maps. By not only publishing the outcome-the written as well as the mapped results-of our study, but also the 'blackbox' (Harley, 1989), the underlying decisions, definitions, and sources, we hope to contribute to a better understanding of long-term urbanization patterns in the North Sea region.

\section{Acknowledgments}

We are grateful for the excellent feedback provided by the anonymous reviewers.

\section{Conflict of Interests}

The authors declare no conflict of interests.

\section{References}

Ayers, B. (2016). The German Ocean: Medieval Europe around the North Sea. Equinox Publishing.

Bairoch, P., Batou, J., \& Chevre, P. (1988). The population of European cities from 800 to 1850: Data bank and short summary of results. Droz.

Blass, T. (2016). The naked shore: Of the North Sea. Bloomsbury Publishing.

Blockmans, W. (2010). Metropolen aan de Noordzee: De geschiedenis van Nederland 1100-1560 [Metropolises on the North Sea: The history of the Netherlands 1100-1560]. Bert Bakker.

Blond, S. J. L. (2013). The Trudaine atlas: Government road mapping in eighteenth-century France. Imago Mundi, 65(1), 64-79.

Boone, M. (2013). Medieval Europe. In P. Clark (Ed.), The Oxford handbook of cities in world history (pp. 221-239). Oxford University Press.

Brand, N. (2011). Waterways and town's interests: The influence of infrastructure on the urban pattern in Holland (1200-1560). OverHolland, 7(10/11), 127-147.

Chandler, T. (1987). Four thousand years of urban growth: A historical census. St. David's University Press.

Couling, N., \& Hein, C. (2020). The North Sea: New perspectives on the sea-land continuum. In N. Couling \& C. Hein (Eds), The urbanisation of the sea: From concepts and analysis to design (pp. 6-15). Nai010 Publishers. 
De Pater, B. (2009). West-Europa: Hoofdlijnen van geografie en ruimtelijke planning [Western Europe: Outlines of geography and spatial planning]. Van Gorcum.

De Vries, J. (1984). European urbanization, 1500-1800. Methuen \& Co.

Desa, U. N. (2014). World urbanization prospects, the 2014 revision. United Nations.

Edwards, P. (2003). Infrastructure and modernity: Force, time, and spatial organization in the history of sociotechnical systems. In T. J. Misa, P. Brey, \& A. Feenberg (Eds.), Modernity and technology (pp. 185-225). MIT Press.

Euratlas. (n.d.). Homepage. https://www.euratlas.net

Eurogeographics. (2017). EuroGlobalMap: Version 10.0 [Data set]. https://eurogeographics.org/maps-foreurope/open-data

Harley, J. B. (1989). Deconstructing the map. Cartographica: The International Journal for Geographic Information and Geovisualization, 26(2), 1-20.

Hein, C., \& van Mil, Y. (2019). Towards a comparative spatial analysis for port city regions based on historical geo-spatial mapping. PORTUSplus, 8(Special Issue).

Hohenberg, P. M., \& Lees, L. H. (1995). The making of urban Europe: 1000-1994. Harvard University Press.

Horsten, F. H. (2005). Doorgaande wegen in Nederland, 16 e to 19 e eeuw [Main roads in the Netherlands, 16 th to 19th century]. Aksant.

Jenks, G. F. (1967). The data model concept in statistical mapping. International Yearbook of Cartography, 7, 186-190.

Kosian, M. C., van Lanen, R. J., \& Weerts, H. J. T. (2016). Nederland in 1575 [The Netherlands in 1575] [Data set]. Nationaal Georegister. http://nationaal georegister.nl/geonetwork/srv/dut/catalog.search\#/ metadata/bda25f76-49ce-4f11-9fc3-99b00900a86a ?tab=general

Kotzeva, M. (2019). Eurostat regional yearbook. European Commission.

Lawton, R., \& Lee, W. R. (2002). Population and society in Western European port cities, C.1650-1939. Liverpool University Press.

Lees, A., \& Lees, L. H. (2013). Europe: 1800-2000. In P. Clark (Ed.), The Oxford handbook of cities in world history (pp. 464-482). Oxford University Press.

Lesger, C. (1993). Intraregional trade and the port system in Holland, 1400-1700. In K. Davids \& L. Noordegraaf (Eds.), The Dutch economy in the Golden Age: Nine studies (pp. 185-217). Nederlands EconomischHistorisch Archief.

Modelski, G. (2003). World cities: -3000 to 2000. FAROS. O'Brien, O., \& Cheshire, J. (2016). Interactive mapping for large, open demographic data sets using familiar geographical features. Journal of Maps, 12(4), 676-683.

Pinol, J. P. (Ed.). (2003). Histoire de l'Europe urbaine [History of the urbanization of Europe]. Edition du Seuil.

Pye, M. (2014). The edge of the world: How the North Sea made us who we are. Penguin Books.

Reba, M., Reitsma, F., \& Seto, K. C. (2016). Spatializing 6,000 years of global urbanization from $3700 \mathrm{BC}$ to AD 2000. Scientific Data, 3(1), 1-16.

Renes, H. (2016). Gebruik van kaarten voor historische onderzoek [Use of maps for historical research]. In M. Hameleers, M. Carnier, P. Alkhoven, \& R. Kruk (Eds.), Cartografie Visie op de kaart [Cartography vision on the map] (Vol. 15, pp. 153-176). Stichting Archiefpublicaties.

Ross, C., \& Clark, J. (2008). London: The illustrated history. Allen Lane.

Rutte, R., \& Abrahamse, J. E. (2016). Atlas of the Dutch urban landscape: A millennium of spatial development. THOTH.

Rutte, R., \& Vannieuwenhuyze, B. (2018). Stedenatlas Jacob van Deventer [Town Atlas of maps made by Jacob van Deventer]. THOTH.

Schipper, F. (2008). Driving Europe: Building Europe on roads in the twentieth century. Eindhoven Technische Universiteit.

Segal, Z. (2020). Flow mapping through the times: The transition from Harness to Nazi propaganda. In Z. Segal \& B. Vannieuwenhuyze (Eds.), Motion in maps, maps in motion: Mapping stories and moving through time (pp. 81-103). Amsterdam University Press.

Terlouw, K. (1996). A general perspective on the regional development of Europe from 1300 to 1850. Journal of Historical Geography, 22(2), 129-146.

Terlouw, K. (2009). Transnational regional development in the Netherlands and Northwest Germany, 1500-2000. Journal of Historical Geography, 35(1), 26-43.

van Mil, Y., \& Rutte, R. (2020a). Ranking cities around the North Sea: Demography, infrastructure and soil [Data set]. DANS. https://doi.org/10.17026/dans-zzg-9vkq

van Mil, Y., \& Rutte, R. (2020b). Ranking cities around the North Sea [Data set]. 4TU. https://doi.org/10.4121/ uuid:975097be-f863-484a-9807-20ec70166305

Verhulst, A. (Ed.). (1996). Anfänge des Städtewesens an Schelde, Maas und Rhein bis zum Jahre 1000 [The genesis of towns on the rivers Scheldt, Meuse and Rhine up to the year 1000]. Böhlau.

Verhulst, A. (1999). The rise of cities in North-West Europe. Cambridge University Press. 


\section{About the Authors}

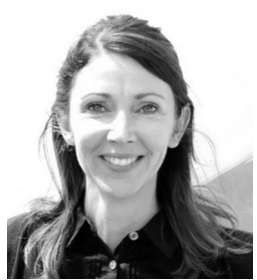

Yvonne van Mil is Researcher in Spatial History and Cartographer, affiliated with Delft University of Technology. Her research topics includes urban and spatial planning in the 19th and 20th century, focusing specifically on regional history and geo-spatial mapping. She was co-author of several books including Driven by Steel: From Hoogovens to Tata Steel 1918-2018 (2018) and contributed chapters to the Atlas of the Dutch Urban Landscape (2016).

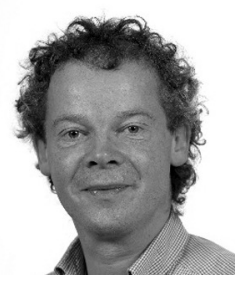

Reinout Rutte is an Urban and Architectural Historian. Since 2004, he has been an Assistant Professor in the Chair History of Architecture and Urban Planning in Delft University of Technology's Faculty of Architecture. Together with Jaap Evert Abrahamse, he published the Atlas of the Dutch Urban Landscape (2016), and together with Bram Vannieuwenhuyze the Stedenatlas Jacob van Deventer (2018). 